Goldschmidt 2021 Abstract

https://doi.org/10.7185/gold2021.6233

\section{Redox-dependent recycling of carbon in subduction zones: a petrological and isotope study from the Belvidere Mountain complex ultramafic body}

\author{
ANTOINE BOUTIER ${ }^{1,2}$, ALBERTO VITALE \\ BROVARONE $^{3}$, ISABELLE MARTINEZ ${ }^{4}$, OLIVIER \\ SISSMANN $^{5}$, SAMUELE AGOSTINI $^{6}$, ISABELLE DANIEL ${ }^{7}$ \\ AND SARA MANA ${ }^{8}$ \\ ${ }^{1}$ Università di Torino \\ ${ }^{2}$ Université Paris Diderot \\ ${ }^{3}$ Università di Bologna \\ ${ }^{4}$ IPGP/ CNRS UMR 7154 \\ ${ }^{5}$ IFP energies nouvelles \\ ${ }^{6}$ Instituto di Geoscienze e Georisorse - CNR \\ ${ }^{7}$ Laboratoire de géologie de Lyon UMR 5276, Université Lyon1 \\ - Ens de Lyon - CNRS \\ ${ }^{8}$ Salem State University \\ Presenting Author: antoine.boutier@gmail.com
}

Subduction is a major actor in the cycling of carbon between surface and deep reservoirs. The fate of carbon in subduction is explored by considering fluid-rock interactions in slab ultramafic rocks and their implications as potential proxies for metasomatism and carbon recycling in the mantle wedge at convergent margins. Ultramafic rocks may record dramatic redox variations affecting the exchanges of deep carbon between solid and fluid phases. The Belvidere Mountain Complex (BMC) is an ultramafic body that underwent Ordovician Taconic subduction up to $510-520{ }^{\circ} \mathrm{C}$ and $0.9-1.3 \mathrm{GPa}$. Preliminary investigations indicate that the BMC experienced partial serpentinization and carbon recycling in the subduction zone (Boutier et al., under review). Here we present MicroRaman data on fluid inclusions, $\delta^{13} \mathrm{C}$ and $\mathrm{Sr}^{87} / \mathrm{Sr}^{86}$ data and numerical modeling results aimed at constraining the pathways of carbon recycling in the BMC. MicroRaman spectroscopy on the fluid inclusions reveals $\mathrm{CH}_{4}$ rich gaseous compositions, along with $\mathrm{N}_{2}, \mathrm{NH}_{3}$ and $\mathrm{S}-\mathrm{H}$ compounds. Methane-rich fluid inclusions can be observed in partially serpentinized peridotites, in carbonate veins and in amphibolite bodies associated with the ultramafic body. The BMC also hosts an exceptional example of graphite deposit up to $3.90 \mathrm{wt} \%$ graphite along a $\sim 6 \mathrm{~m}$-thick vein within the serpentinized ultramafic body and along lithologic contacts. The $\delta^{13} \mathrm{C}$ composition of the graphite clusters at $-15 \%$ (VPBD). Carbonates present in the system have $\delta^{13} \mathrm{C}$ values ranging from -2.8 to $-4.8 \%$. Preliminary investigations on $\delta^{13} \mathrm{C}$ of methane in fluid inclusions yield value of $-13 \%$. The ${ }^{87} \mathrm{Sr} /{ }^{86} \mathrm{Sr}$ ratio advocate for fluid infiltration from metasedimentary rocks, which is further suggested by the abundance of nitrogen and carbon in the fluid inclusions. The release of serpentinizationrelated methane from the BMC is proposed as the mechanism leading to graphite precipitation. Numerical modeling suggests that the graphite precipitation was triggered by processes of fluid dehydration and mixing, possibly related to the serpentinization event, and/or by redox barriers. Further complexity is suggested by the presence of carbonate reduction in samples. The BMC rocks highlight the variability of carbon recycling in a dynamic fluid-rock system, with carbon mobilization and sink adapting to evolving redox conditions. 